\title{
SOLVABILITY FOR A SYSTEM OF NONLINEAR FRACTIONAL HIGHER-ORDER THREE-POINT BOUNDARY VALUE PROBLEM
}

\author{
SABBAVARAPU NAGESWARA RAO
}

Abstract. Existence of eigenvalues yielding single and multiple positive solutions for a system of higher order fractional differential equations along with boundary conditions is established. The results are obtained by the use of a Guo-Krasnosel'skii fixed point theorem in cones.

Mathematics subject classification (2010): 34B09, 34B15, 34B18, 34B27.

Keywords and phrases: Fractional differential equation, eigenvalues, positive solution, fixed point theorem, Green's function, cone.

\section{REFERENCES}

[1] R. P. Agarwal, D. O'Regan, V. Lakshmikantham, Singular $(p, n-p)$ focal and $(n, p)$ higher order boundary value problems, Nonlinear Anal. 42 (2) (2000) 215-228.

[2] B. Ahmad, S. K. NTOUYAS, A note on fractional differential equations with fractional separated boundary conditions, Abstr. Appl. Anal. 2012, Article ID 818703 (2012).

[3] B. AhmAD, S. K. NTOUYAS, Existence results for a coupled system of Caputo type sequential fractional differential equations with nonlocal integral boundary conditions, Appl. Math. Comput. 266 (2015) 615-622.

[4] A. N. Abd-alla, A. M. Hamdan, I. Giorgio and D. Del Vescovo, The mathematical model of reflection and refraction of longitudinal waves in thermo-piezoelectric materials, Archive of Applied Mechanics 84 (2014) 1229-1248.

[5] I. A. Abbas, A. N. AbD-Alla, F. A. Alzahrani And M. Spagnuolo, Wave propagation in a generalized thermoelastic plate by using eigenvalue approach, Journal of Thermal Stresses 39 (11) (2016) 1367-1377.

[6] J. V. BAXley, C. R. Houmand, Nonlinear higher order boundary value problems with multiple positive solutions, J. Math. Anal. Appl. 286 (2) (2003) 682-691.

[7] D. Baleanu, K. Diethelm, E. Scalas, J. J. Trujillo, Fractional Calculus Models and Numerical Methods. Series on Complexity, Nonlinearity and Chaos, World Scientific, Boston (2012).

[8] S. DAS, Functional Fractional Calculus for System Identification and Control, Springer, New York (2008).

[9] P. W. Eloe, B. Ahmad, Positive solutions of a nonlinear $n$th order boundary value problem with nonlocal conditions, Appl. Math. Lett. 18 (5) (2005) 521-527.

[10] J. R. Graef, T. Moussaoui, A class of nth-order BVPs with nonlocal conditions, Comput. Math. Appl. 58 (8) (2009) 1662-1671.

[11] D. Guo, V. Lakshmikantham, Nonlinear Problems in Abstract Cones, Academic Press, Orlando (1988).

[12] Y. Guo, Solvability for a nonlinear fractional differential equation, Bull. Aust. Math. Soc, 80 (1) (2009) 125-138.

[13] J. HENDERSON, R. LUCA, Existence of positive solutions for a system of higher-order multi-point boundary value problems, Appl. Math. Comput. 219 (2012) 3709-3720.

[14] J. Henderson, R. LuCA, A. Tudorache, On a system of fractional differential equations with coupled integral boundary conditions, Fract. Calc. Appl. Anal. 18 (2015) 361-386.

[15] J. Henders on, R. LUCA, A. Tudorache, Positive solutions for a fractional boundary value problem, Nonlinear Stud. 22 (2015) 1-13. 
[16] M. A. KRasnosel's KII, Positive Solutions of Operator Equations, Noordhoff Groningen, Netherland, 1964.

[17] A. A. Kilbas, H. M. Srivastava, J. J. Trujillo, Theory and Applications of Fractional Differential Equations, North-Holland Mathematics Studies 204, Elsevier Science B. V., Amsterdam 2006.

[18] K. R. Prasad, S. Nageswararao, P. Murali, Solvability of a nonlinear general third order two-point eigenvalue problem on time scales, Differ. Equ. Dyn. Syst. 17 (3) (2009) 269-282.

[19] W. LI, Positive solutions for higher order singular nonlinear ordinary differential systems, Int. J. Nonlinear Sci. 9 (2010) 28-40.

[20] S. Liang, J. Zhang, Positive solutions for boundary value problems of nonlinear fractional differential equations, Nonlinear Anal. 71 (2009) 5545-5550.

[21] K. S. Miller, B. Ross, An introduction to the Fractional Calculus and Fractional Differential Equations, Wiley, New York (1993).

[22] S. NAGESWARARAO, Existence of multiple positive solutions for the system of nonlinear fractional order boundary value problem, International Journal of Analysis and Applications 11 (2) (2016), 8192.

[23] S. NAGESWARARAO, Existence of positive solutions for Riemann-Liouville fractional order threepoint boundary value problem, Asian-Eur. J. Math. 8 (4) (2015) DOI: 10.1142/S1793557115500576.

[24] S. NAGES WARARAO, Multiple positive solutions for a system of Riemann-Liouville fractional order two-point boundary value problems, Panamer. Math. J. 25 (1) (2015) 66-81.

[25] S. NAGESWARARAO, Existence and multiplicity for a system of fractional higher-order two-point boundary value problem, J. Appl. Math. Comput. 51 (2016), 93-107, DOI 10.1007/s 12190-0150893-7.

[26] S. N. RAO, Multiplicity of Positive Solutions for Fractional Differential Equation with p-Laplacian Boundary Value Problems, Int. J. Differ. Equ. 2016, Article ID 6906049, 10 pages, DOI: 10.1155/2016/6906049.

[27] S. N. RAO, Eigenvalues for Iterative Systems of Nonlinear Fractional Order Boundary Value Problems with p-Laplacian, Int. J. Appl. Comput. Math. (2016), DOI:10.1007/s40819-016-0263-7.

[28] S. N. RAO, Multiplicity of positive solutions for coupled system of fractional differential equation with p-Laplacian two-point BVPs, J. Appl. Math. Comput. (2016), DOI:10.1007/s12190-016-1024-9.

[29] I. Podlubny, Fractional Differential Equations, Academic Press, San Diego, 1999.

[30] J. Sabatier, O. P. Agrawal, J. A. T. Machado (Eds.), Advances in Fractional Calculus: Theoretical Developments and Applications in Physics and Engineering, Springer, Dordrecht, 2007.

[31] H. M. SRivastava, R. K. SAXENA, Operators of fractional integration and their applications, Appl. Math. Comput. 118 (2001) 1-52.

[32] H. M. SRivastava, S. Owa, K. Nishimoto, Some fractional differintegral equations, J. Math. Anal. Appl. 106 (1985) 360-366. 